\title{
404. Neue Möglichkeit zur Charakterisierung und Identifizierung gastrointestinaler Tumorzellen durch Bestimmung ihrer CEA- und EMA-Antigenmuster
}

\author{
R. Wirsching ${ }^{1}$, L. Rüssmann ${ }^{2}$, G. Valet ${ }^{2}$, J. Koller $^{1}$ und M. Ormerod ${ }^{3}$ \\ ${ }^{1}$ Chirurgische Klinik und Poliklinik, Universität München, Klinikum Großhadern, \\ Marchioninistraße 15, D-8000 München 70, \\ ${ }^{2}$ Arbeitsgruppe Krebszellforschung, Max-Planck-Institut, Martinsried, \\ ${ }^{3}$ Institut of Cancer Research, Sutton, Surrey, UK
}

\section{A New Method for Characterization and Identification of Gastrointestinal Tumor Cells by Flow Cytometry Determination of CEA- and EMA}

\begin{abstract}
Summary. Singe-cell suspensions of gastrointestinal carcinoma and mucosa were stained with fluorescent dyes for determination of carcinoembryonic antigen (CEA) and epithelial membrane antigen (EMA). According to measurements in a Fluvo-Metricell flow cytometer and computerized data analysis the carcinomas contained between $1 \%$ and $30 \%$ of CEA- and EMA-positive cells. In the GO/Gl cell cycle phase there was a substantial antigen presence; this was rare in populations with higher degrees of chromosome set multiplication. In twothirds of the patients the mucosa was negative or only slightly stained, while in the remaining third it was stained to a moderate degree or almost as intensely as the tumor.
\end{abstract}

Key words: Gastrointestinal tumor cells - Flow cytometry - Carcinoembryonic antigen - Epithelial membrane antigen.

Zusammenfassung. Einzelzellsuspensionen gastrointestinaler Carcinome bzw. Mucosa wurden fluorescenzmarkiert zur simultanen Bestimmung von carcinoembryonalem (CEA) bzw. epithelialem Membranantigen (EMA) und DNA-Gehalt. Die Messung im Fluvo-Metricell-Durchflußcytometer ergab bei den Carcinomen zwischen $1 \%$ und $30 \%$ CEA- bzw. EMA-positive Zellen. Ausgeprägte Antigenmarkierung fand sich in der GO/GlZellcyclusphase, seltener bei höherploiden Populationen. Die Mucosa war bei ${ }^{2} / 3$ der Patienten negativ oder schwach markiert, bei $1 / 3$ mäßig bis nahezu gleich stark positiv wie der Turmor.

Schlüsselwörter: Gastrointestinale Tumorzellen - Durchflußcytometrie - Carcinoembryonales Antigen Epitheliales Membranantigen.

\section{Sklerosierung der Oesophaguswand bei Ratten}

\section{J. Erhard, K. Metz, E. Gross und G. Dostal}

Abteilung für Allgemein-Chirurgie (Dir.: Prof. Dr. F. W. Eigler) Klinikum der GHS Essen, Hufelandstraße 55, D-4300 Essen 1

\section{Sclerosis of the Esophageal Wall in Rats}

Summary. In 64 male Wistar rats the distal wall of the esophagus underwent submucosal sclerosis as a result of exposure to different substances. (Four groups of 16 animals each received $5 \%$ or $1 \%$ ethoxysclerol, $1 \%$ phenolalmond oil, or $10 \% \mathrm{NaCl}$ solution.) The results were checked by histological examinations in progress at specific times: no differences were found between the various substances. Progression from submucosal edema (day 25) to a fibrous granulation took 3 weeks; sclerosis was seen after 4 months. The frequency of such complications as wall penetration by necroses was found to be similarly low with all four substances.

Key words: Esophageal sclerosis - Sclerosing solutions - Pathological findings.

Zusammenfassung. An 64 männlichen Wistar-Ratten wurde die distale Oesophaguswand mit verschiedenen Substanzen (jeweils 16 Tiere mit 0,5 und $1 \%$ igem Aethoxysklerol, $1 \%$ igem Phenolmandelöl und $10 \%$ iger NaClLösung) submucös sklerosiert. Das Ergebnis wurde im zeitlichen Ablauf histologisch überprüft: für die verschiedenen Substanzen ergaben sich keine Unterschiede. Über ein submucöses Ödem (2. Tag), eine fibröse Granulation ( 3 Wochen) fand sich nach 4 Monaten eine Sklerose. Komplikationen wie wanddurchgreifende Nekrosen waren für alle Substanzen in gleicher geringer Häufigkeit anzutreffen.

Schlüsselwörter: Oesophagussklerosierung - Sklerosierungssubstanzen - pathologische Beurteilung. 